\title{
Oleanolic Acid Attenuates Insulin Resistance via NF- $\kappa$ B to Regulate the IRS1-GLUT4 Pathway in HepG2 Cells
}

\author{
Ming Li, Zongyu Han, Weijian Bei, Xianglu Rong, Jiao Guo, and Xuguang Hu \\ Key Unit of Modulating Liver to Treat Hyperlipemia SATCM (State Administration of Traditional Chinese Medicine), \\ Level 3 Lab of Lipid Metabolism SATCM, Guangdong TCM Key Laboratory for Metabolic Diseases, \\ Guangdong Pharmaceutical University, Guangzhou Higher Education Mega Centre, Guangzhou 510006, China
}

Correspondence should be addressed to Jiao Guo; gyguoyz@163.com and Xuguang Hu; hxguang21@163.com

Received 10 October 2015; Revised 9 December 2015; Accepted 15 December 2015

Academic Editor: Yuewen Gong

Copyright (C) 2015 Ming Li et al. This is an open access article distributed under the Creative Commons Attribution License, which permits unrestricted use, distribution, and reproduction in any medium, provided the original work is properly cited.

\begin{abstract}
The aim of our study is to elucidate the mechanisms of oleanolic acid (OA) on insulin resistance (IR) in HepG2 cells. HepG2 cells were induced with FFA as the insulin resistance model and were treated with OA. Then the glucose content and the levels of tumor necrosis factor- $\alpha$ (TNF- $\alpha$ ) and interleukin-6 (IL-6) were analyzed. Moreover, protein expression of nuclear factor kappa B (NF$\kappa \mathrm{B}$ ), insulin receptor substrate 1 (IRS1), and glucose transporter 4 (GLUT4) in cells treated with OA were measured by Western blot analysis. Additionally, IRS1 protein expression exposed to OA was detected after using pyrrolidine dithiocarbamate (PDTC).Our results revealed that OA decreased the glucose content in HepG2 cells in vitro. Moreover, OA reduced the levels of TNF- $\alpha$ and IL- 6 and upregulated IRS1 and GLUT4 protein expression. Furthermore, OA also reduced NF- $\kappa$ B protein expression in insulin-resistant HepG2 cells. After blocking NF- $\kappa$ B, the expression of IRS1 protein had no obvious changes when treated with OA. OA attenuated insulin resistance and decreased the levels of TNF- $\alpha$ and IL-6. Meanwhile, OA decreased NF- $\kappa$ B protein expression and upregulated IRS1 and GLUT4 protein expression. Therefore, regulating the IRS1-GLUT4 pathway via NF- $\kappa$ B was the underlying mechanism of $\mathrm{OA}$ on insulin resistance.
\end{abstract}

\section{Introduction}

Most pathology ultimately arises from obesity's characteristic milieu of chronic low-grade inflammation and insulin resistance [1]. The inability of insulin to perform normal biological functions in vivo is called insulin resistance. In general, insulin resistance occurs when a certain concentration of insulin cannot effectively stimulate glucose uptake and utilization in the peripheral target organs. Thus the organism suffers from impaired glucose tolerance that ultimately leads to diabetes or other diseases [2-4]. Many studies have demonstrated that patients with insulin resistance (IR) have displayed an increased risk of developing diabetes, cardiovascular disease, and other diseases $[5,6]$.

Recent studies have found that metabolic diseases including obesity are a common cause of insulin resistance. Meanwhile, increases in FFA (sodium oleate, Figure 1) levels have been shown to occur in metabolic diseases [7-9]. Higher FFA levels could induce the body to secrete inflammatory cytokines, such as TNF- $\alpha$ or IL- 6 , which would be a lowgrade inflammatory state. Inflammation induced by FFA plays a key role in insulin resistance $[10,11]$. As the important target of the inflammatory pathways, NF- $\kappa \mathrm{B}$ could disrupt IRS1 and downregulate the expression of IRS1 under conditions of insulin resistance $[12,13]$.

Oleanolic acid (OA), a naturally occurring triterpenoid (Figure 2), is the main effective active ingredient in many herbs such as glossy privet fruit and exists largely in food products (vegetable oils) [14].

Preliminary study found that OA had blood glucosereducing effect and inhibited insulin resistance in diabetic rats [15]. OA decreased blood glucose, improved insulin resistance, and enhanced insulin signaling by inhibition of ROS and anti-inflammatory effect in diabetic mice [16]. OA also regulated the NF- $\kappa$ B signaling which exhibits high antiinflammatory activity and was regarded as a potential NF$\kappa \mathrm{B}$ inhibitor [17]. Recently a study conducted by Li et al. demonstrated that $\mathrm{OA}$ ameliorated insulin resistance via 


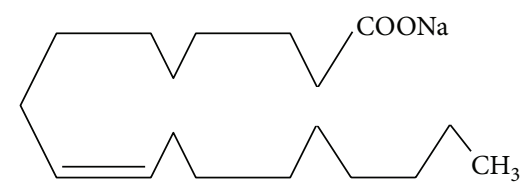

FIGURE 1: Chemical structure of sodium oleate.

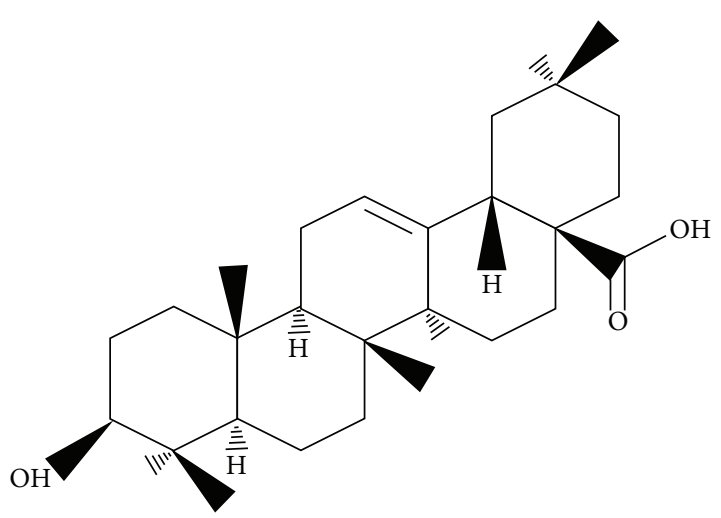

Figure 2: Chemical structure of oleanolic acid.

the IRS-1/PI3k/Akt pathway in rats [18]. Although previous evidence showed that $\mathrm{OA}$ attenuated insulin resistance in part through inhibiting inflammation and enhancing the IRS-1 signal, the role of $\mathrm{NF}-\kappa \mathrm{B}$ in attenuating insulin resistance by OA remains essentially unknown.

To further elucidate the molecular mechanisms of OA on insulin resistance and investigate the role of $\mathrm{NF}-\kappa \mathrm{B}$ in regulating IRS-1 signal by OA, the levels of TNF- $\alpha$ and IL6 were analyzed and protein expression of nuclear factor kappa B (NF- $\kappa \mathrm{B})$, insulin receptor substrate 1 (IRS1), and glucose transporter 4 (GLUT4) in insulin-resistant HepG2 cells treated with $\mathrm{OA}$ was measured. In addition, IRS1 protein expression exposed to OA was detected after NF- $\kappa \mathrm{B}$ was blocked using pyrrolidine dithiocarbamate (PDTC).

\section{Methods and Materials}

HepG2 cells were purchased from Landbiology (Guangzhou, China, lot: HB-8065). Dulbecco's modified Eagle's medium (DMEM) was bought from GIBCO (Gibco, Grand Island, NY, USA, lot: 8114176). Fetal bovine serum (FBS) was purchased from Biological Industries (Israel, lot: 1415878). NF$\kappa \mathrm{B}$, IRS1, and GLUT4 antibodies were from Abcam Inc. (Cambridge, UK, lot: GR165665-1; GR95405-9; GR565661). Rosiglitazone (RSG) was bought from Sigma (St. Louis, MO, USA, lot: R2408-10 mg). Sodium oleate was bought from Tokyo Chemical Industry (Tokyo, Japan, lot: W76EC-0J). All other reagents were analytical grade. A GOD-POD kit was purchased from Biosino Bio-Technology and Science Inc. (Beijing, China, lot: 143271). ELISA kits were bought from Raybiotech Inc. (Norcross, GA, USA, Human TNF- $\alpha$, lot: 0926140193; human IL-6, lot: 0926140140). Oleanolic acid (OA) was purchased from the National Institutes for Food and Drug Control (Beijing, China, lot: 110709-200505).
2.1. Cell Culture. The human hepatocellular carcinoma cell line HepG2 was purchased from Land Unicomed. Cells were cultured in DMEM supplemented with 10\% heat-inactivated FBS at $37^{\circ} \mathrm{C}$ in a $5 \% \mathrm{CO}_{2}$ atmosphere. In all experiments, the cells were grown to $80-90 \%$ confluence.

2.2. Cell Viability Assay. The cytotoxicity of OA against the HepG2 cells was assessed by the MTT assay. The MTT viability assay was described previously [19]. Briefly, HepG2 cells were plated in 96-well plates at $1 \times 10^{5}$ cells per well. After $24 \mathrm{~h}, \mathrm{HepG} 2$ cells were treated with indicated dose of $\mathrm{OA}$ at $37^{\circ} \mathrm{C}$ for $24 \mathrm{~h}$; MTT stock solution $(20 \mu \mathrm{L} ; 5 \mathrm{mg} / \mathrm{mL}$ in PBS) was added to each well to achieve a total reaction volume of $220 \mu \mathrm{L}$. After $4 \mathrm{~h}$ of incubation at $37^{\circ} \mathrm{C}$ and $5 \% \mathrm{CO}_{2}$, the media were then removed and $150 \mu \mathrm{L}$ dimethyl sulfoxide (DMSO) was added to every well. After shaking for $10 \mathrm{~min}$, the amount of purple formazan was assessed by measuring the absorbance at $490 \mathrm{~nm}$.

2.3. Induction of Insulin Resistance in HepG2 Cells and Glucose Utilization Experiments. The HepG2 cells were cultured and determination of glucose utilization was performed as previously described [20]. Briefly, HepG2 cells were seeded on 24well plates at $1 \times 10^{5}$ cells/well and incubated for $24 \mathrm{~h}$ to reach maximal confluence. The cells were then incubated for $24 \mathrm{~h}$ in serum-free DMEM, $0.2 \% \mathrm{BSA}$, and $200 \mu \mathrm{mol} / \mathrm{L}$ sodium oleate in the absence or presence of OA (OA was dissolved in DMSO) or RSG. Next, cells were washed twice with PBS and incubated for $3 \mathrm{~h}$ in serum-free DMEM containing $25 \mathrm{mmol} / \mathrm{L}$ d-glucose and $1 \times 10^{-9} \mathrm{~mol} / \mathrm{L}$ insulin. The culture medium was collected. The content of glucose was quantified using a GOD-POD kit.

2.4. Enzyme-Linked Immunosorbent Assay of TNF- $\alpha$ and IL6 Levels. Insulin resistance was induced in HepG2 cells as previously described. The culture medium was centrifuged at $14000 \times \mathrm{g}$ for 10 minutes at $4^{\circ} \mathrm{C}$. The supernatant was then collected and stored at $-80^{\circ} \mathrm{C}$ until analysis. The levels of TNF- $\alpha$ and IL- 6 in the supernatant were determined using ELISA kits according to the manufacturer's instructions.

2.5. Western Blot Analysis. Insulin resistance was induced in HepG2 cells as previously described. Cells were washed with ice-cold PBS and lysed with a RIPA lysis buffer. For Western blotting, protein samples $(20 \mu \mathrm{g})$ of sodium oleate induced insulin-resistant HepG 2 cells were separated via $10 \%$ sodium dodecyl sulfate-polyacrylamide gel electrophoresis (SDS-PAGE). The proteins were transferred to a PVDF membrane and incubated with primary antibody (anti-NF$\kappa \mathrm{B}$, anti-IRS1, anti-GLUT4, or anti-GAPDH), followed by a secondary antibody (horseradish peroxidase-conjugated anti-rabbit IgG). The intensity of the immunoblot signal was assayed using Western Bright ECL spray and analyzed quantitatively using GeneTools software from Syngene (Syngene, Cambridge, UK).

To choose the most effective concentration of PDTC, the cells were incubated for $26 \mathrm{~h}$ in serum-free DMEM at the different dosages of PDTC or $0.2 \%$ BSA and $200 \mu \mathrm{mol} / \mathrm{L}$ sodium 


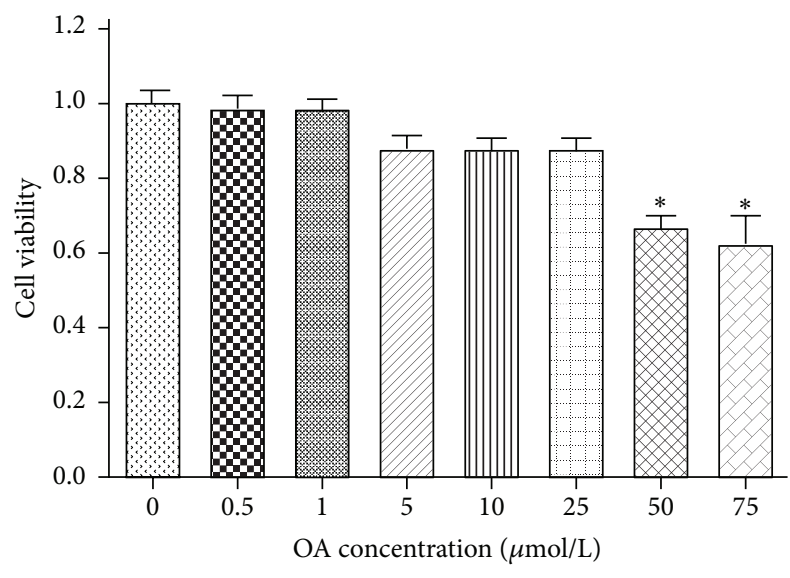

FIgure 3: Influence of OA on the cell viability in HepG2 cells. 1 $\times 10^{5}$ cells per well were seeded into a 96-well plate; cells were stimulated with various concentrations of $\mathrm{OA}\left(1-75 \mu \mathrm{mol} \mathrm{L}^{-1}\right)$ for $24 \mathrm{~h}$; cell viability was measured by $\mathrm{MTT}^{*}{ }^{*} \mathrm{P}<0.05$.

oleate. The protein samples were prepared for Western blot experiments and incubated with anti-NF- $\kappa \mathrm{B}$.

Then, the cells were incubated for $2 \mathrm{~h}$ in serum-free DMEM and PDTC with the most effective concentration (all PDTC groups). After that, $0.2 \% \mathrm{BSA}$ and $200 \mu \mathrm{mol} / \mathrm{L}$ sodium oleate and three dosages of OA were added. Next, the cells were incubated for an additional $24 \mathrm{~h}$ after preparing the protein samples in Western blot experiments and incubated with anti-IRS1.

2.6. Statistics Analysis. The statistical analyses were conducted using SPSS16.0 software. All results are presented as the mean \pm standard deviation (SD). Statistical analyses were performed using analysis of variance (one-way ANOVA) followed by the Student-Newman-Keuls test for significance. The differences were considered to be statistically significant at $P<0.05$.

\section{Result}

3.1. Influence of $\mathrm{OA}$ on the Cell Viability in HepG2 Cells. The influence of OA on the cell viability in HepG2 cells was examined using the MTT reduction assay. The MTT assay results demonstrated no significant difference in cell viability of cells treated with $\mathrm{OA}$ at the concentrations of lower than $50 \mu \mathrm{mol} / \mathrm{L}$. As the concentration of OA was $75 \mu \mathrm{mol} / \mathrm{L}$, the cell viability was reduced by approximately $40 \%$ when compared to the control treatment (Figure 3).

\subsection{Effect of $O A$ on the Glucose Content of the Culture Media} in Insulin-Resistant HepG2 Cells. The HepG2 cells were incubated for $24 \mathrm{~h}$ in serum-free DMEM containing $200 \mu \mathrm{mol} / \mathrm{L}$ sodium oleate, in either $0.5,1,5,10$, and $25 \mu \mathrm{mol} / \mathrm{L}$ OA or RSG $(10 \mu \mathrm{mol} / \mathrm{L})$. Next, the cells were incubated for $3 \mathrm{~h}$ in insulin. The glucose content in the insulin-resistant HepG2 cells in culture medium was significantly increased compared with

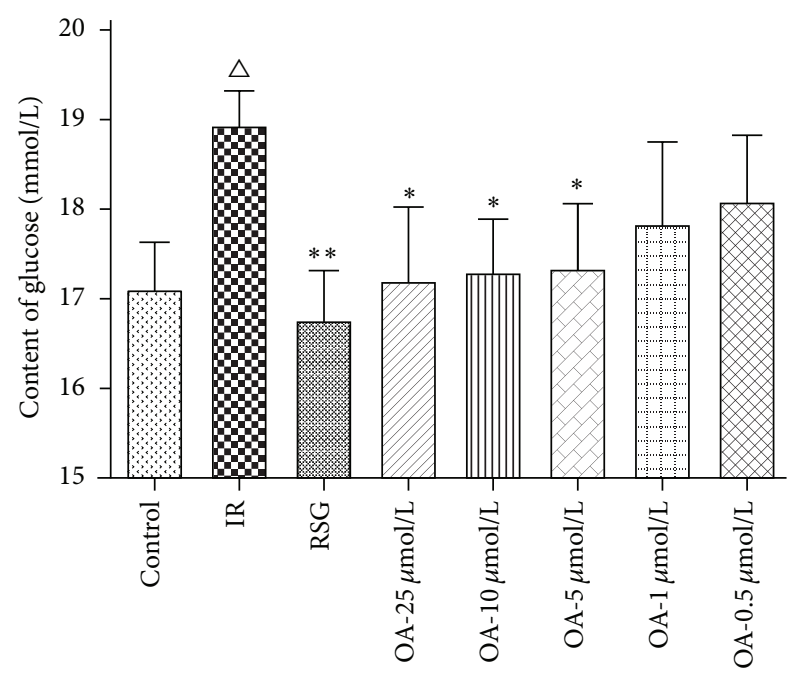

FIGURE 4: Effect of OA on the glucose content of the culture media in HepG2 cells. ${ }^{\triangle} P<0.01$ compared with the control cells; ${ }^{* *} P<0.01$, ${ }^{*} P<0.05$ compared with the IR cells.

the control cells $(P<0.01)$. After treatment with $\mathrm{OA}(5,10$, and $25 \mu \mathrm{mol} / \mathrm{L}$ ), the glucose content in the culture medium significantly reduced compared with the IR cells $(P<0.05)$. Rosiglitazone (RSG), which is the insulin sensitizer as a positive control drug, decreased the glucose content in the culture medium compared with the IR cells $(P<0.01)$. These results showed that $\mathrm{OA}$ attenuated insulin resistance in a dose-dependent manner (Figure 4).

3.3. Effect of OA on the Levels of TNF- $\alpha$ and IL-6 in InsulinResistant HepG2 Cells. To examine the effect of OA on inflammatory cytokines, the levels of TNF- $\alpha$ and IL-6 in the culture media of insulin-resistance HepG2 cells were measured by ELISA. The HepG2 cells were incubated for $24 \mathrm{~h}$ in serum-free DMEM containing $200 \mu \mathrm{mol} / \mathrm{L}$ sodium oleate, in the 5,10 , and $25 \mu \mathrm{mol} / \mathrm{L} \mathrm{OA}$, or in RSG $(10 \mu \mathrm{mol} / \mathrm{L})$. The levels of TNF- $\alpha$ and IL- 6 in insulin-resistant HepG2 cells were significantly higher compared with the control cells $(P<$ $0.01)$. After treatment with $\mathrm{OA}(5,10$, and $25 \mu \mathrm{mol} / \mathrm{L})$, the level of IL- 6 in the culture medium was significantly lower compared with the IR cells $(P<0.01)$. Moreover, treatment with $\mathrm{OA}$ at the dosages of 10 and $25 \mu \mathrm{mol} / \mathrm{L}$ significantly lowered the levels of TNF- $\alpha$ in the culture medium compared with the IR cells $(P<0.05 ; P<0.01)$. Moreover, after treatment with OA at a dosage of $5 \mu \mathrm{mol} / \mathrm{L}$, the level of TNF- $\alpha$ in the culture medium did not obviously decrease compared with the IR cells. RSG was also able to decrease all of the levels of TNF- $\alpha$ and IL- 6 in the culture medium compared with the IR cells $(P<0.01)$ (Figure 5).

3.4. Effect of $O A$ on the Protein Expression of NF- $\kappa B$, IRS1, and GLUT4 in Insulin-Resistant HepG2 Cells. To elucidate the mechanism of OA on insulin resistance in HepG2 cell, a 


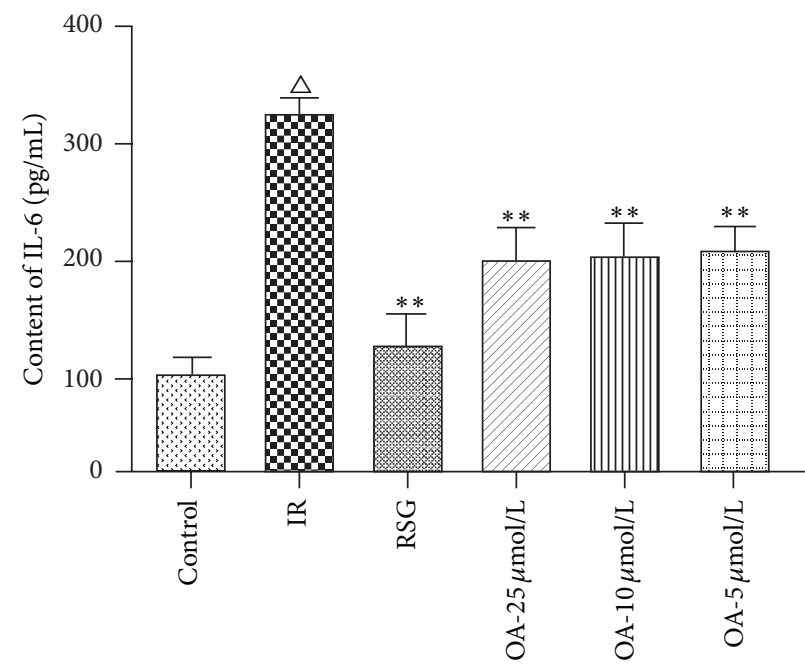

(a)

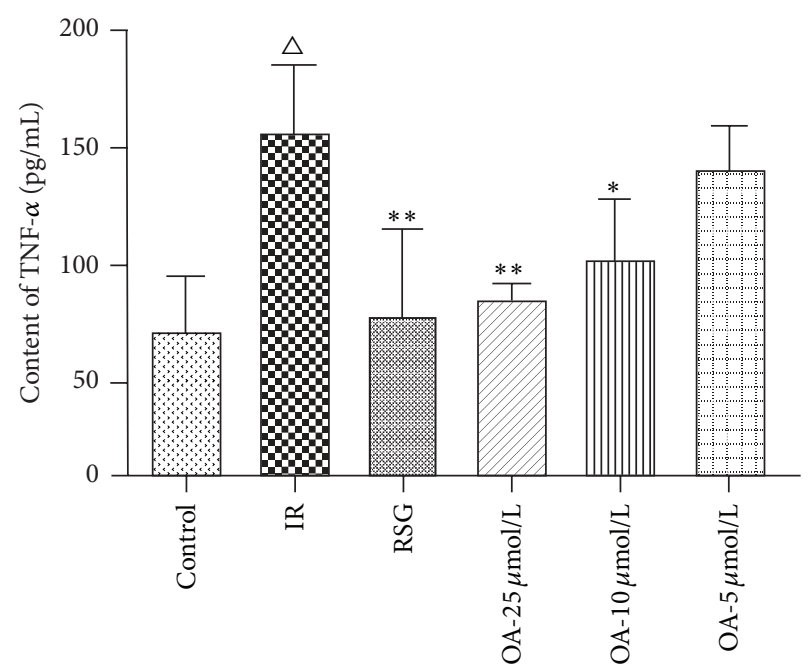

(b)

Figure 5: Effect of OA on TNF- $\alpha$ and IL-6 levels in HepG2 cells. ${ }^{\triangle} P<0.01$ compared with the control cells; ${ }^{* *} P<0.01,{ }^{*} P<0.05$ compared with the IR cells.

Western blot analysis was used to measure the protein expression of NF- $\kappa$ B, IRS1, and GLUT4 in HepG 2 cells. The cells were divided into six groups, including a Control group, IR group $(200 \mu \mathrm{mol} / \mathrm{L}$ sodium oleate), RSG group $(200 \mu \mathrm{mol} / \mathrm{L}$ sodium oleate and RSG $10 \mu \mathrm{mol} / \mathrm{L}), \mathrm{OA}-25 \mu \mathrm{mol} / \mathrm{L}$ group $(200 \mu \mathrm{mol} / \mathrm{L}$ sodium oleate, OA $25 \mu \mathrm{mol} / \mathrm{L}), \mathrm{OA}-10 \mu \mathrm{mol} / \mathrm{L}$ group $(200 \mu \mathrm{mol} / \mathrm{L}$ sodium oleate, OA $10 \mu \mathrm{mol} / \mathrm{L})$, and OA$5 \mu \mathrm{mol} / \mathrm{L}$ group $(200 \mu \mathrm{mol} / \mathrm{L}$ sodium oleate, OA $5 \mu \mathrm{mol} / \mathrm{L})$. As shown in Figure 4, the expression of NF- $\kappa \mathrm{B}$ protein in the IR group was significantly greater than the Control group $(P<0.01)$. IRS1 and GLUT4 protein expression in the IR group was significantly reduced compared with the Control group $(P<0.01)$. After treatment with $\mathrm{OA}$ at three dosages, the protein expression of $\mathrm{NF}-\kappa \mathrm{B}$ was significantly reduced compared with the IR group $(P<0.01)$. In addition, the expression of IRS1 and GLUT4 protein with OA at three dosages was significantly higher compared with the IR group $(P<0.01)$. RSG was also able to increase the expression of IRS1 and GLUT4 protein and reduce the expression of NF- $\kappa \mathrm{B}$ protein compared with the IR group $(P<0.01)$ (Figure 6).

3.5. Effect of PDTC on NF- $\kappa B$ Protein Expression in HepG2 Cells. To select the most effective concentration of PDTC that blocked NF- $\kappa \mathrm{B}$ expression using Western blot analysis, HepG2 cells were divided into six groups, including a Control group, $100 \mu \mathrm{mol} / \mathrm{L}$ PDTC group, $300 \mu \mathrm{mol} / \mathrm{L}$ PDTC group, $500 \mu \mathrm{mol} / \mathrm{L}$ PDTC group, $1000 \mu \mathrm{mol} / \mathrm{L}$ PDTC group, and IR group $(200 \mu \mathrm{mol} / \mathrm{L}$ sodium oleate). The levels of NF- $\kappa \mathrm{B}$ expression in all groups that were treated with PDTC were significantly lower than the Control group $(P<0.01)$. The expression of NF- $\kappa \mathrm{B}$ in the IR group was significantly greater than the Control group $(P<0.01)$. As shown in Figure 5, the most effective concentration of PDTC that blocked NF$\kappa \mathrm{B}$ expression was $300 \mu \mathrm{mol} / \mathrm{L}$ (Figure 7 ).

\subsection{Effect of OA on the Expression of IRS1 Protein in Insulin-Resistant HepG2 Cells with Blocking of the Expression of $N F-\kappa B$}

Figure 8(a). To study the IRS1 protein expression when PDTC exists or not, HepG2 protein samples were divided into four groups as follows: Control group, IR group $(200 \mu \mathrm{mol} / \mathrm{L}$ sodium oleate), P + Control group (300 $\mu \mathrm{mol} / \mathrm{L}$ PDTC), and $\mathrm{P}+\mathrm{IR}$ group $(300 \mu \mathrm{mol} / \mathrm{L}$ PDTC and $200 \mu \mathrm{mol} / \mathrm{L}$ sodium oleate). As shown in Figure 6(a), the expression of IRS1 protein in the $\mathrm{P}+$ Control group was significantly greater than the Control group $(P<0.01)$. In addition, the expression of IRS1 protein in $\mathrm{P}+\mathrm{IR}$ group was significantly increased compared with the IR group $(P<0.01)$ and significantly reduced compared with the $\mathrm{P}+$ Control group $(P<0.05)$.

Figure $8(b)$. To evaluate the effect of OA on the IRS1 protein expression when PDTC exists or not, HepG2 protein samples were divided into nine groups as follows: Control group, IR group $(200 \mu \mathrm{mol} / \mathrm{L}$ sodium oleate), OA- $25 \mu \mathrm{mol} / \mathrm{L}$ group $(200 \mu \mathrm{mol} / \mathrm{L}$ sodium oleate, $25 \mu \mathrm{mol} / \mathrm{L} \mathrm{OA}), \mathrm{OA}-10 \mu \mathrm{mol} / \mathrm{L}$ group $(200 \mu \mathrm{mol} / \mathrm{L}$ sodium oleate, $10 \mu \mathrm{mol} / \mathrm{L}$ OA $)$, OA$5 \mu \mathrm{mol} / \mathrm{L}$ group $(200 \mu \mathrm{mol} / \mathrm{L}$ sodium oleate, $5 \mu \mathrm{mol} / \mathrm{L} \mathrm{OA}), \mathrm{P}$ + IR group ( $300 \mu \mathrm{mol} / \mathrm{L}$ PDTC, $200 \mu \mathrm{mol} / \mathrm{L}$ sodium oleate), $\mathrm{P}$ + OA-25 $\mu \mathrm{mol} / \mathrm{L}$ group $(300 \mu \mathrm{mol} / \mathrm{L}$ PDTC, $200 \mu \mathrm{mol} / \mathrm{L}$ sodium oleate and $25 \mu \mathrm{mol} / \mathrm{L} \mathrm{OA}), \mathrm{P}+\mathrm{OA}-10 \mu \mathrm{mol} / \mathrm{L}$ group (300 $\mu \mathrm{mol} / \mathrm{L}$ PDTC, $200 \mu \mathrm{mol} / \mathrm{L}$ sodium oleate and $10 \mu \mathrm{mol} /$ $\mathrm{L}$ OA), and $\mathrm{P}+\mathrm{OA}-5 \mu \mathrm{mol} / \mathrm{L}$ group $(300 \mu \mathrm{mol} / \mathrm{L}$ PDTC, $200 \mu \mathrm{mol} / \mathrm{L}$ sodium oleate and $5 \mu \mathrm{mol} / \mathrm{L} \mathrm{OA})$. As shown in Figure 6(b), the expression of IRS1 protein in the IR group was significantly lower than the Control group $(P<0.01)$; the expression of IRS1 protein in the OA-25 $\mu \mathrm{mol} / \mathrm{L}$ group, OA-10 $\mu \mathrm{mol} / \mathrm{L}$ group, OA-5 $\mu \mathrm{mol} / \mathrm{L}$ group, $\mathrm{P}+$ IR group, $\mathrm{P}+$ OA-25 $\mathrm{mol} / \mathrm{L}$ group, $\mathrm{P}+\mathrm{OA}-10 \mu \mathrm{mol} / \mathrm{L}$ group, and $\mathrm{P}+$ 

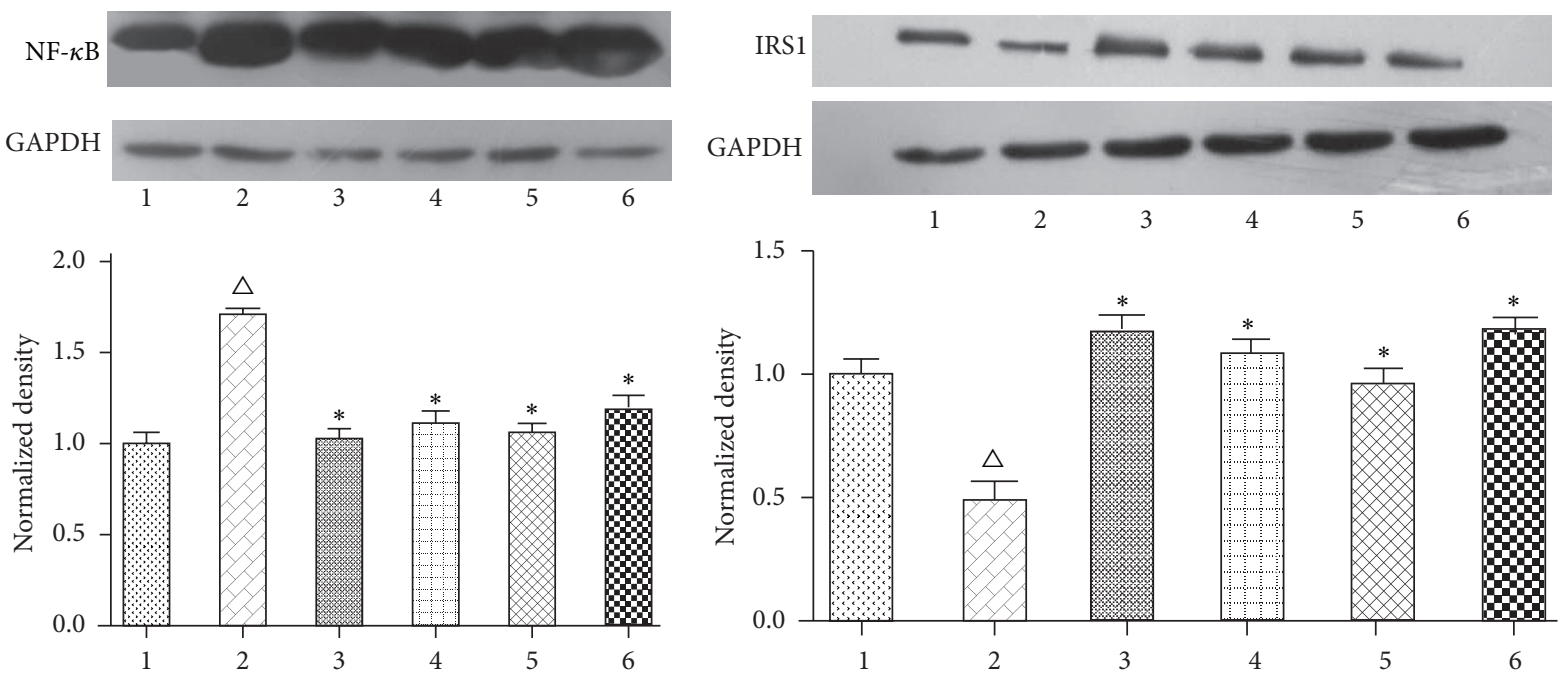

(a)

(b)
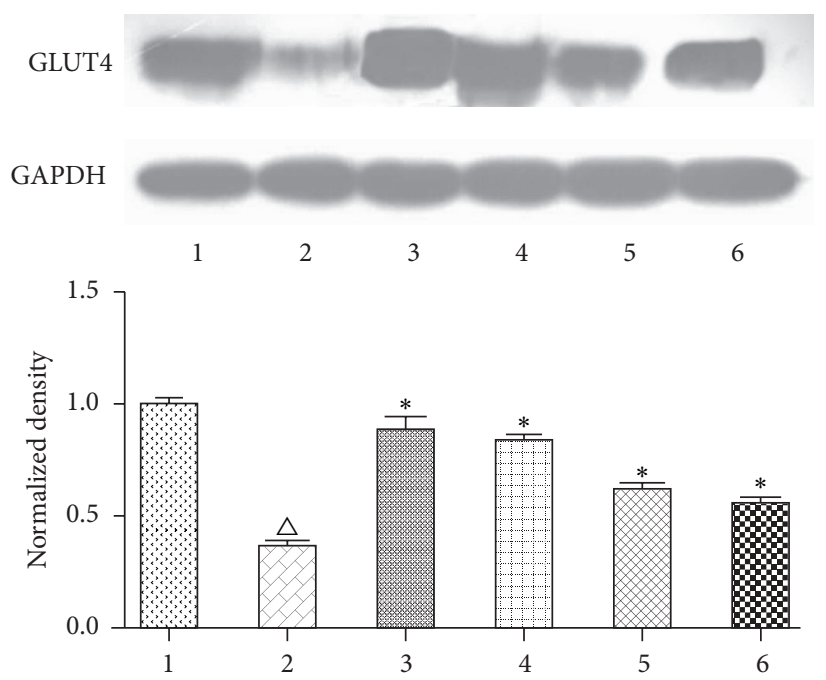

(c)

Figure 6: Effect of OA on NF- $\kappa$ B, IRS1, and GLUT4 protein expression. (1) Control; (2) IR; (3) RSG; (4) OA-25 $\mu \mathrm{mol} / \mathrm{L}$; (5) OA-10 $\mu \mathrm{mol} / \mathrm{L}$; (6) OA-5 $\mu \mathrm{mol} / \mathrm{L}$. The protein expression of NF- $\kappa \mathrm{B}$, IRS1, and GLUT4 was measured via Western blotting as described in the text. The figures represent one of three experiments with similar results. ${ }^{\triangle} P<0.01$ compared with the Control group; ${ }^{*} P<0.01$ compared with the IR group.

OA-5 $\mu \mathrm{mol} / \mathrm{L}$ group was significantly greater than the IR group $(P<0.01)$. When compared to the three dosages of OA without PDTC, the expression of IRS1 protein in three dosages of OA with PDTC was reduced $(P<0.05)$ (Figure 8$)$.

\section{Discussion}

This study demonstrated that OA attenuated insulin resistance in HepG2 cells, whose effect is possibly mediated through decreasing the levels of TNF- $\alpha$ and IL- 6 and regulating the expression of IRS1 and GLUT4 protein via the NF- $\kappa \mathrm{B}$ protein.

Elevated levels of free fatty acids are thought to be the pathogenic factors causing metabolic disorders such as obesity and diabetes [21]. Oleate, an unsaturated fatty acid, can induce insulin resistance in HepG2 cells [22]. HepG2 cells were wildly used for studying insulin resistance [23]. When HepG2 cells were induced with insulin resistance, their responses to glucose were affected. The glucose content in insulin-resistant cells in culture medium increased compared with healthy cells [24]. In the present study, we used $200 \mu \mathrm{mol} / \mathrm{L}$ sodium oleate to induce insulin resistance in HepG2 cells. The glucose content in the IR group in culture medium was significantly greater than the Control groups. It showed that it is a suitable model of insulin resistance.

Oleanolic acid (OA) exerts multiple pharmacological actions including glycoregulatory, hepatoprotective, antiinflammatory, and antioxidant effects and is used to treat chronic diseases, such as diabetes, liver injury, and hepatitis [25]. A study conducted by Wang et al. found that OA decreased the glucose content in the culture medium, 

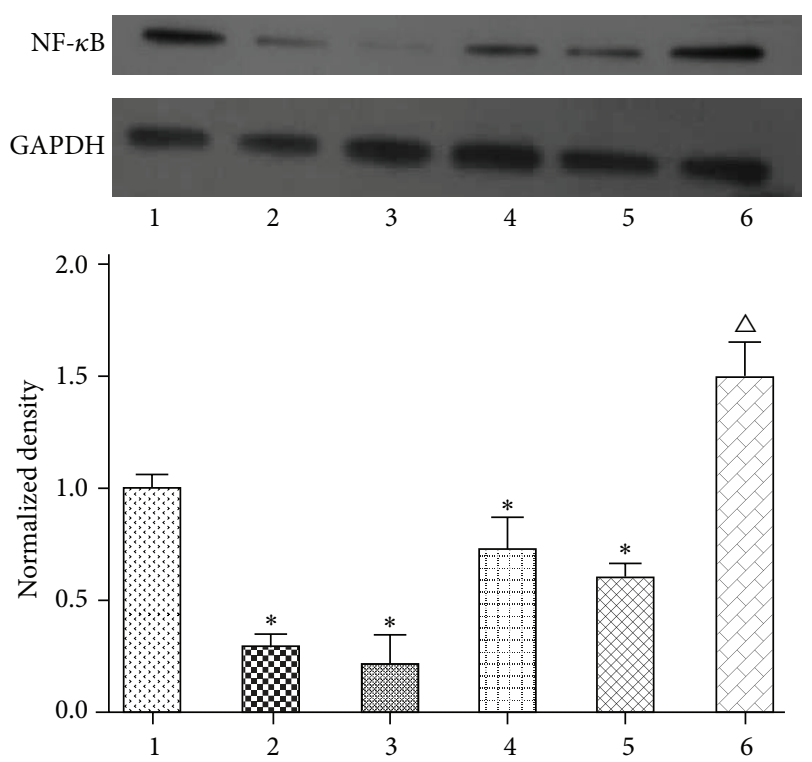

Figure 7: Effect of PDTC on NF- $\kappa$ B protein expression. (1) Control; (2) PDTC-100 $\mu \mathrm{mol} / \mathrm{L}$; (3) PDTC-300 $\mu \mathrm{mol} / \mathrm{L}$; (4) PDTC$500 \mu \mathrm{mol} / \mathrm{L}$; (5) PDTC-1000 $\mu \mathrm{mol} / \mathrm{L}$; (6) IR. The protein expression of NF- $\kappa$ B was measured via Western blotting as described in the text. The figures represent one of three experiments with similar results. ${ }^{\triangle} P<0.01$ compared with the Control group; ${ }^{*} P<0.01$ compared with the Control group.

improved insulin resistance, protected beta-cell, and inhibited the mitochondrial apoptosis in beta-TC3 cells [26]. de Melo et al.s study [27] showed that OA reduced blood glucose and improved glucose tolerance in mice. Our study results showed that OA decreased the glucose content in the culture medium at variable dosage in HepG2 cells. It demonstrated that $\mathrm{OA}$ affected the glucose utilization and attenuated insulin resistance in dose-dependent manner (Figure 2). Consistence with our study, Teodoro et al. [28] found that OA enhanced insulin secretion and increased the glucose utilization in pancreatic beta-cells in vitro.

High levels of FFA could induce insulin resistance as well as inflammation [29]. Much research has shown that OA had an anti-inflammatory effect and reduced the content of inflammatory cytokines, such as TNF- $\alpha$ and IL-6. Chai et al. found that OA decreased the level of IL- 6 and TNF- $\alpha$ in the serum and liver of $\mathrm{db} / \mathrm{db}$ mice [30]. Liu et al. showed that OA could inhibit the generation of the inflammatory factors TNF- $\alpha$ and IL-6 [31]. Nkeh-Chungag et al. found that OA exerted potent anti-inflammatory effects by inhibiting NO and PGE2 in RAW 264.7 cells [32]. Our results showed that OA decreased the levels of IL- 6 and TNF- $\alpha$ in insulinresistant HepG2 cells (Figure 3).

Mounting evidence has suggested that inflammatory processes were related to the pathogenesis of insulin resistance [33]. The NF- $\kappa \mathrm{B}$ is a pivotal molecular mediator of insulin resistance [34]. Various inflammatory cytokines, including IL- 6 and TNF- $\alpha$, have been shown to activate NF- $\kappa$ B to cause insulin resistance [35]. Insulin resistance causes the impairment of IRS1 and GLUT4, which lead to obstacle of glucose utilization [36]. As mentioned above, OA has anti-inflammatory effects. It not only reduced the content of inflammatory cytokines but also reduced the expression of NF- $\kappa \mathrm{B}$ and upregulated IRS1 protein expression. Kim et al. found that OA could disturb NF- $\kappa$ B activation in 3T3L1 adipocytes by inhibiting inflammatory responses during adipocyte differentiation through blocking IL-6-TRAF6-NF$\kappa \mathrm{B}$ signaling [37]. Li et al's results showed that OA could upregulate IRS1 protein expression in adipose tissue in insulin-resistant rats. Our studies showed that insulin resistance induced by sodium oleate could lead to overexpression of NF- $\kappa \mathrm{B}$ protein and that IRS1 and GLUT4 proteins were impaired. After treatment with OA, the expression of NF- $\kappa \mathrm{B}$ protein was significantly reduced and the expression of IRS1 and GLUT4 protein was partially restored.

Pyrrolidine dithiocarbamate (PDTC) is a specific NF$\kappa \mathrm{B}$ inhibitor that becomes widely used [38]. In Zheng et al.s study, PDTC was used to block NF- $\kappa$ B to explain the protective effects of chronic resveratrol treatment on vascular inflammatory injury in streptozotocin-induced type 2 diabetic rats [39]. To illustrate the point that OA could relieve the expression of the IRS1 and GLUT4 by blocking the expression of NF- $\kappa \mathrm{B}$, PDTC was used to block NF- $\kappa \mathrm{B}$ in our study. We found that the expression of IRS1 protein in the cells of the IR group that were previously blocked by PDTC was significantly elevated compared with IR group cells without PDTC. After the addition of OA at three dosages, the expression of IRS1 protein in the OA groups was significantly higher than those in the IR group. The expression of IRS1 protein in the OA groups with PDTC was not increased as obviously as the OA groups that were not exposed to PDTC. Therefore, we thought that NF- $\kappa \mathrm{B}$ was the potential key target of $\mathrm{OA}$ that relieved insulin resistance. According to the results of Figure 4, OA could reduce the expression of NF- $\kappa$ B protein and directly increase the expression of IRS1. As mentioned above, PDTC is a specific NF- $\kappa \mathrm{B}$ inhibitor. Meanwhile, the expression of IRS1 would increase when NF- $\kappa$ B was blocked. Based on the above knowledge, we speculated that OA can relieve insulin resistance by directly affecting the expression of IRS1 protein. OA also affected the expression of IRS1 protein indirectly by regulating $\mathrm{NF}-\kappa \mathrm{B}$. When $\mathrm{NF}-\kappa \mathrm{B}$ was blocked by PDTC, OA could not affect IRS1 by NF- $\kappa$ B. Thus, the effect of OA on the expression of IRS1 protein in cells was attenuated compared to those without PDTC.

\section{Conclusions}

In conclusion, our study indicated that OA could decrease insulin resistance by reducing the content of inflammatory cytokines in culture medium. Regulating the IRS1-GLUT4 pathway via $\mathrm{NF}-\kappa \mathrm{B}$ was the underlying mechanism of the effects of OA on insulin resistance. Our findings may provide new insights into the mechanisms underlying the effect of oleanolic acid in insulin-resistant cells.

\section{Abbreviations}

IR: Insulin resistance

OA: Oleanolic acid 


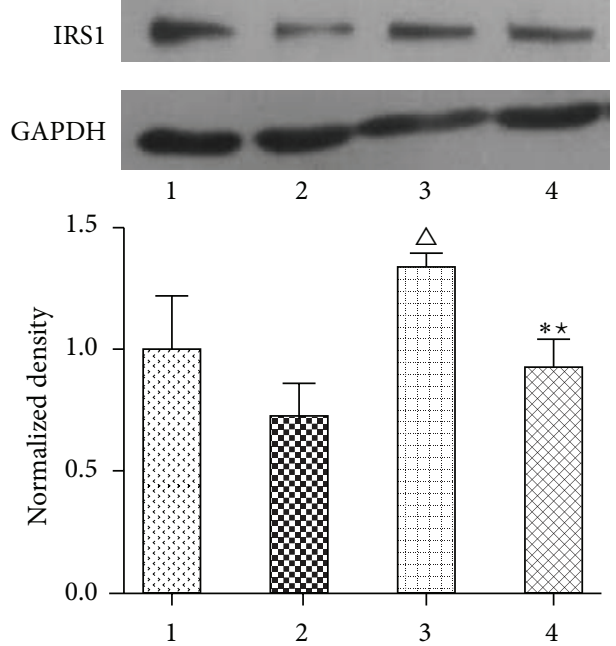

(a)

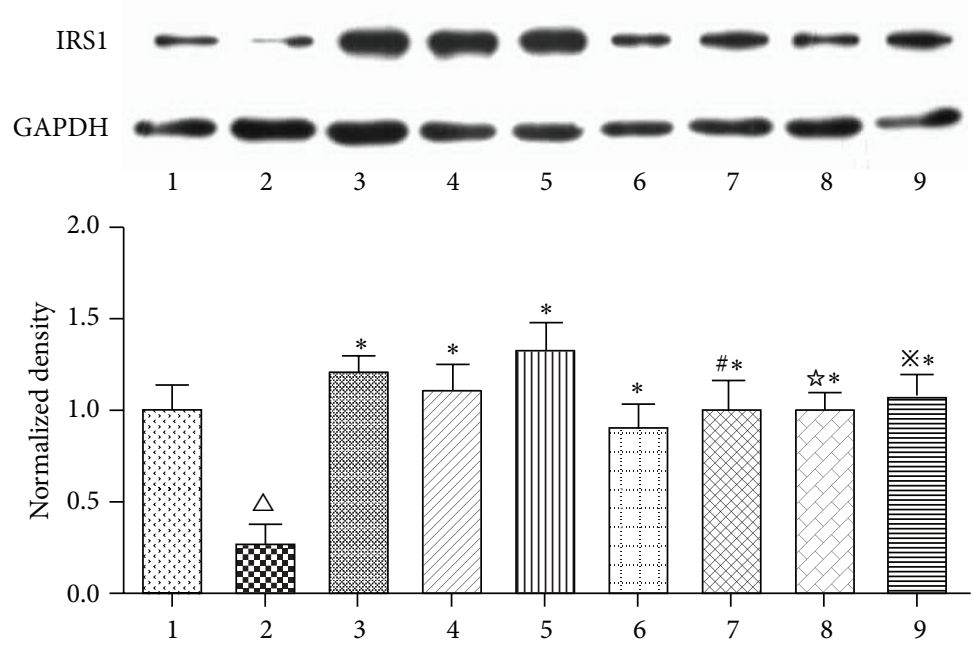

(b)

FIgURE 8: Effect of OA on IRS1 protein expression with blocking of the expression of NF- $\kappa$ B. (a) (1) Control; (2) IR; (3) P + Control; (4) P + IR. (b) (1) Control; (2) IR; (3) OA-25 $\mu \mathrm{mol} / \mathrm{L}$; (4) OA-10 $\mu \mathrm{mol} / \mathrm{L}$; (5) OA-5 $\mu \mathrm{mol} / \mathrm{L}$; (6) P + IR; (7) P + OA-25 $\mu \mathrm{mol} / \mathrm{L}$; (8) P + OA-10 $\mu \mathrm{mol} / \mathrm{L}$; (9) $\mathrm{P}+\mathrm{OA}-5 \mu \mathrm{mol} / \mathrm{L}$. The protein expression of IRS1 was measured via Western blotting as described in the text. The figures represent one of three experiments with similar results. ${ }^{\circ} P<0.01$ compared with the Control group; ${ }^{*} P<0.01$ compared with the IR group; ${ }^{*} P<0.05$ compared with the P + Control group; ${ }^{\#} P<0.05$ compared with the OA-25 $\mu \mathrm{mol} / \mathrm{L}$ group; ${ }^{\text {in }} P<0.05$ compared with the OA-10 $\mu \mathrm{mol} / \mathrm{L}$ group; ${ }^{*} P<0.05$ compared with the OA-5 $\mu \mathrm{mol} / \mathrm{L}$ group.

FFA: $\quad$ Free fatty acid

TNF- $\alpha$ : Tumor necrosis factor- $\alpha$

IL-6: Interleukin-6

NF- $\kappa$ B: Nuclear factor kappa B

IRS1: Insulin receptor substrate 1

GLUT4: Glucose transporter 4

PDTC: Pyrrolidine dithiocarbamate

ELISA: Enzyme-linked immunosorbent assay

RSG: Rosiglitazone

DMEM: Dulbecco's modified Eagle's medium

FBS: $\quad$ Fetal bovine serum

DMSO: Dimethyl sulfoxide.

\section{Disclosure}

This paper does not contain any studies on human or animal subjects performed by any of the authors.

\section{Conflict of Interests}

The authors declare that they have no conflict of interests.

\section{Authors' Contribution}

Dr. Jiao Guo and Xuguang Hu designed the study. Ming Li and Zongyu Han carried out experiments. Weijian Bei and Xianglu Rong participated in the design of study. Dr. B. Han, MC Fang, L. Wan, and M. Wang have provided a lot of support and help. All authors have read and approved the final paper.

\section{Acknowledgments}

This study was supported by grants from the Natural Sciences Funds, China (no. 81173626, 2011), Guangdong Province-Chinese Education Ministry Industry, Education and Research Cooperation Project (no. 2011B090400379), and Guangdong Province Natural Sciences Funds Research Team Project (no. 10351022401000000).

\section{References}

[1] J. I. Odegaard and A. Chawla, "Pleiotropic actions of insulin resistance and inflammation in metabolic homeostasis," Science, vol. 339, no. 6116, pp. 172-177, 2013.

[2] G. M. Reaven, "Role of insulin resistance in human disease," Diabetes, vol. 37, no. 12, pp. 1595-1607, 1988.

[3] K. Choi and Y.-B. Kim, "Molecular mechanism of insulin resistance in obesity and type 2 diabetes," Korean Journal of Internal Medicine, vol. 25, no. 2, pp. 119-129, 2010.

[4] K. Makki, P. Froguel, and I. Wolowczuk, "Adipose tissue in obesity-related inflammation and insulin resistance: cells, cytokines, and chemokines," ISRN Inflammation, vol. 2013, Article ID 139239, 12 pages, 2013.

[5] L. Pedersen, M. Nybo, M. Poulsen, J. Henriksen, J. Dahl, and L. Rasmussen, "Plasma calprotectin and its association with cardiovascular disease manifestations, obesity and the metabolic syndrome in type 2 diabetes mellitus patients," BMC Cardiovascular Disorders, vol. 14, article 196, 2014.

[6] S. K. Panchal, H. Poudyal, A. Iyer et al., "High-carbohydrate, high-fat diet-induced metabolic syndrome and cardiovascular remodeling in rats," Journal of Cardiovascular Pharmacology, vol. 57, no. 5, pp. 611-624, 2011. 
[7] J. M. Castellano, A. Guinda, T. Delgado, M. Rada, and J. A. Cayuela, "Biochemical basis of the antidiabetic activity of oleanolic acid and related pentacyclic triterpenes," Diabetes, vol. 62, no. 6, pp. 1791-1799, 2013.

[8] E. Fjære, U. L. Aune, K. Røen et al., "Indomethacin treatment prevents high fat diet-induced obesity and insulin resistance but not glucose intolerance in C57BL/6J mice," The Journal of Biological Chemistry, vol. 289, no. 23, pp. 16032-16045, 2014.

[9] G. Boden, "Obesity, insulin resistance and free fatty acids," Current Opinion in Endocrinology, Diabetes and Obesity, vol. 18, no. 2, pp. 139-143, 2011.

[10] Q. Huang, J. Xue, R. Zou et al., "NR4A1 is associated with chronic low-grade inflammation in patients with type 2 diabetes," Experimental and Therapeutic Medicine, vol. 8, no. 5, pp. 16481654, 2014.

[11] B.-C. Lee and J. Lee, "Cellular and molecular players in adipose tissue inflammation in the development of obesity-induced insulin resistance," Biochimica et Biophysica Acta-Molecular Basis of Disease, vol. 1842, no. 3, pp. 446-462, 2014.

[12] D. Zhang and P. S. Leung, "Potential roles of GPR120 and its agonists in the management of diabetes," Drug Design, Development and Therapy, vol. 8, pp. 1013-1027, 2014.

[13] G. Boden, P. She, M. Mozzoli et al., "Free fatty acids produce insulin resistance and activate the proinflammatory nuclear factor- $\kappa$ b pathway in rat liver," Diabetes, vol. 54 , no. 12 , pp. $3458-$ 3465, 2005.

[14] K. Xu, F. Chu, G. Li et al., "Oleanolic acid synthetic oligoglycosides: a review on recent progress in biological activities," Pharmazie, vol. 69, no. 7, pp. 483-495, 2014.

[15] X. Wang, Y.-L. Li, H. Wu et al., "Antidiabetic effect of oleanolic acid: a promising use of a traditional pharmacological agent," Phytotherapy Research, vol. 25, no. 7, pp. 1031-1040, 2011.

[16] X. Wang, R. Liu, W. Zhang et al., "Oleanolic acid improves hepatic insulin resistance via antioxidant, hypolipidemic and antiinflammatory effects," Molecular and Cellular Endocrinology, vol. 376, no. 1-2, pp. 70-80, 2013.

[17] Y.-J. Hwang, J. Song, H.-R. Kim, and K.-A. Hwang, "Oleanolic acid regulates NF- $\kappa \mathrm{B}$ signaling by suppressing MafK expression in RAW 264.7 cells," BMB reports, vol. 47, no. 9, pp. 524-529, 2014.

[18] Y. Li, J. Wang, T. Gu, J. Yamahara, and Y. Li, "Oleanolic acid supplement attenuates liquid fructose-induced adipose tissue insulin resistance through the insulin receptor substrate-1/ phosphatidylinositol 3-kinase/Akt signaling pathway in rats," Toxicology and Applied Pharmacology, vol. 277, no. 2, pp. 155$163,2014$.

[19] Z. Song, H. Wang, L. Zhu et al., "Curcumin improves high glucose-induced INS-1 cell insulin resistance via activation of insulin signaling," Food \& Function, vol. 6, no. 2, pp. 461-469, 2015.

[20] D. Gao, S. W. Nong, X. Q. Huang et al., “The effects of palmitate on hepatic insulin resistance are mediated by NADPH oxidase 3-derived reactive oxygen species through JNK and p38 MAPK pathways," The Journal of Biological Chemistry, vol. 285, no. 39, pp. 29965-29973, 2010.

[21] Y. Luo, P. Rana, and Y. Will, "Palmitate increases the susceptibility of cells to drug-induced toxicity: an in vitro method to identify drugs with potential contraindications in patients with metabolic disease," Toxicological Sciences, vol. 129, no. 2, pp. 346-362, 2012.

[22] A. Chabowski, M. Zendzian-Piotrowska, K. Konstantynowicz et al., "Fatty acid transporters involved in the palmitate and oleate induced insulin resistance in primary rat hepatocytes," Acta Physiologica, vol. 207, no. 2, pp. 346-357, 2013.

[23] A. Aravinthan, B. Challis, N. Shannon, M. Hoare, J. Heaney, and G. J. M. Alexander, "Selective insulin resistance in hepatocyte senescence," Experimental Cell Research, vol. 331, no. 1, pp. 38 45, 2015.

[24] X. G. Hu, M. Wang, W. J. Bei, Z. Y. Han, and J. Guo, "The Chinese herbal medicine FTZ attenuates insulin resistance via IRS1 and PI3K in vitro and in rats with metabolic syndrome," Journal of Translational Medicine, vol. 12, no. 1, article 47, 2014.

[25] J. Pollier and A. Goossens, "Oleanolic acid," Phytochemistry, vol. 77, pp. 10-15, 2012.

[26] X. Wang, H. L. Chen, J. Z. Liu et al., "Protective effect of oleanoleanolic olic acid against beta cell dysfunction and mitochondrial apoptosis: crucial role of ERK-NRF2 signaling pathway," Journal of Biological Regulators and Homeostatic Agents, vol. 27, no. 1, pp. 55-67, 2013.

[27] C. L. de Melo, M. G. R. Queiroz, S. G. C. Fonseca et al., "Oleanolic acid, a natural triterpenoid improves blood glucose tolerance in normal mice and ameliorates visceral obesity in mice fed a high-fat diet," Chemico-Biological Interactions, vol. 185, no. 1, pp. 59-65, 2010.

[28] T. Teodoro, L. Zhang, T. Alexander, J. Yue, M. Vranic, and A. Volchuk, "Oleanolic acid enhances insulin secretion in pancreatic $\beta$-cells," FEBS Letters, vol. 582, no. 9, pp. 1375-1380, 2008.

[29] P. Han, Y.-Y. Zhang, Y. Lu, B. He, W. Zhang, and F. Xia, "Effects of different free fatty acids on insulin resistance in rats," Hepatobiliary and Pancreatic Diseases International, vol. 7, no. 1, pp. 91-96, 2008.

[30] J. Chai, X. Du, S. Chen et al., "Oral administration of oleanolic acid, isolated from Swertia mussotii Franch, attenuates liver injury, inflammation, and cholestasis in bile duct-ligated rats," International Journal of Clinical and Experimental Medicine, vol. 8, no. 2, pp. 1691-1702, 2015.

[31] J. Liu, X. Wang, R. Liu et al., "Oleanolic acid co-administration alleviates ethanol-induced hepatic injury via Nrf-2 and ethanolmetabolizing modulating in rats," Chemico-Biological Interactions, vol. 221, pp. 88-98, 2014.

[32] B. N. Nkeh-Chungag, O. O. Oyedeji, A. O. Oyedeji, and E. J. Ndebia, "Anti-inflammatory and membrane-stabilizing properties of two semisynthetic derivatives of oleanolic acid," Inflammation, vol. 38, no. 1, pp. 61-69, 2015.

[33] D. P. Arçari, W. Bartchewsky Jr., and T. W. dos Santos, "Antiinflammatory effects of yerba maté extract (Ilex paraguariensis) ameliorate insulin resistance in mice with high fat diet-induced obesity," Molecular and Cellular Endocrinology, vol. 335, no. 2, pp. 110-115, 2011.

[34] M. K. Moon, M. Kim, S. S. Chung et al., "S-Adenosyl-L-methionine ameliorates TNF $\alpha$-induced insulin resistance in 3T3-L1 adipocytes," Experimental and Molecular Medicine, vol. 42, no. 5, pp. 345-352, 2010.

[35] S. E. Shoelson, J. Lee, and A. B. Goldfine, "Inflammation and insulin resistance," The Journal of Clinical Investigation, vol. 116, no. 7, pp. 1793-1801, 2006.

[36] S. Schinner, W. A. Scherbaum, S. R. Bornstein, and A. Barthel, "Molecular mechanisms of insulin resistance," Diabetic Medicine, vol. 22, no. 6, pp. 674-682, 2005.

[37] H.-S. Kim, S.-Y. Han, H.-Y. Sung et al., "Blockade of visfatin induction by oleanolic acid via disturbing IL-6-TRAF6-NF- $\kappa \mathrm{B}$ signaling of adipocytes," Experimental Biology and Medicine, vol. 239, no. 3, pp. 284-292, 2014. 
[38] R. Madonna, Y.-J. Geng, R. Bolli et al., "Co-activation of nuclear factor $-\kappa \mathrm{B}$ and myocardin/serum response factor conveys the hypertrophy signal of high insulin levels in cardiac myoblasts," Journal of Biological Chemistry, vol. 289, no. 28, pp. 19585-19598, 2014.

[39] X. Zheng, S. Zhu, S. Chang et al., "Protective effects of chronic resveratrol treatment on vascular inflammatory injury in streptozotocin-induced type 2 diabetic rats: role of NF- $\kappa$ B signaling," European Journal of Pharmacology, vol. 720, no. 1-3, pp. 147-157, 2013. 


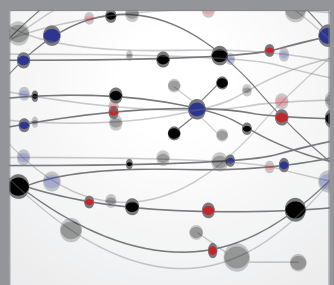

The Scientific World Journal
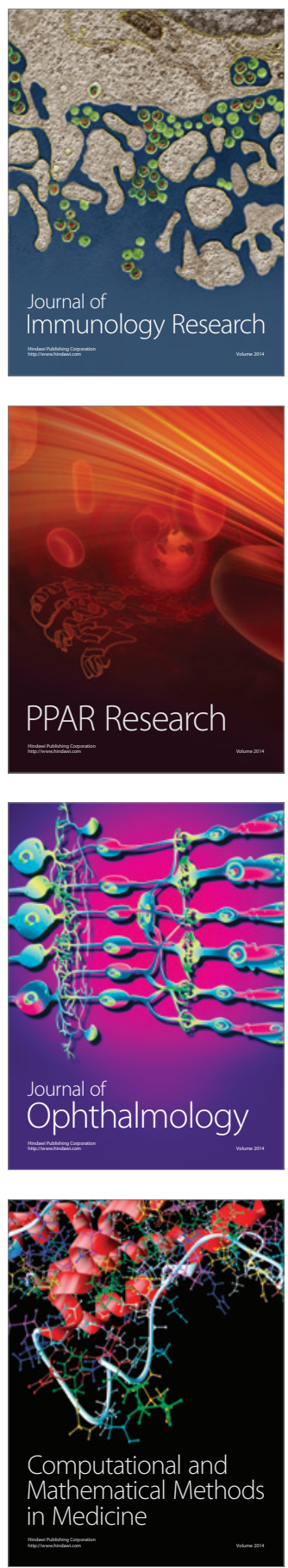

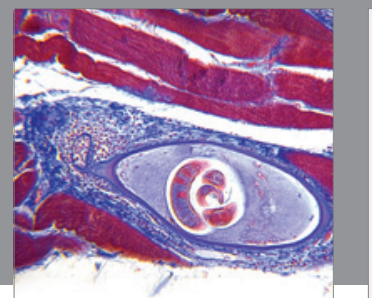

Gastroenterology

Research and Practice
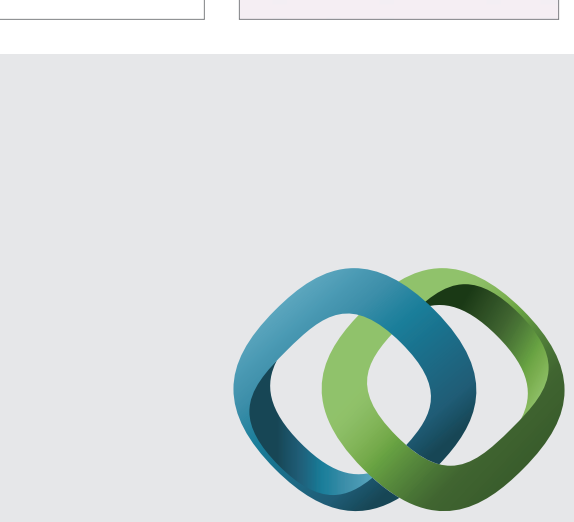

\section{Hindawi}

Submit your manuscripts at

http://www.hindawi.com
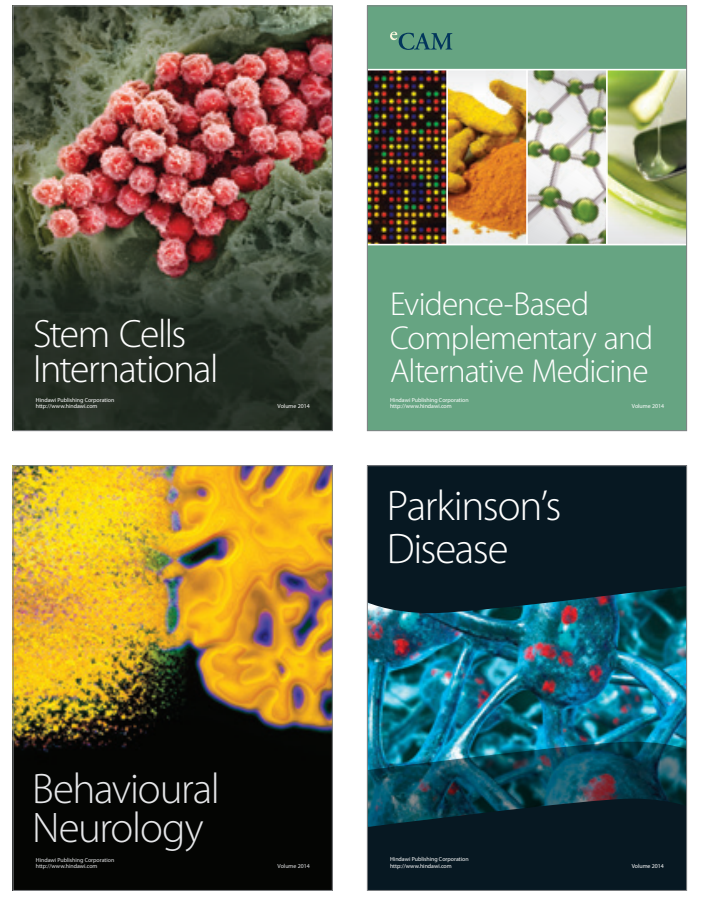
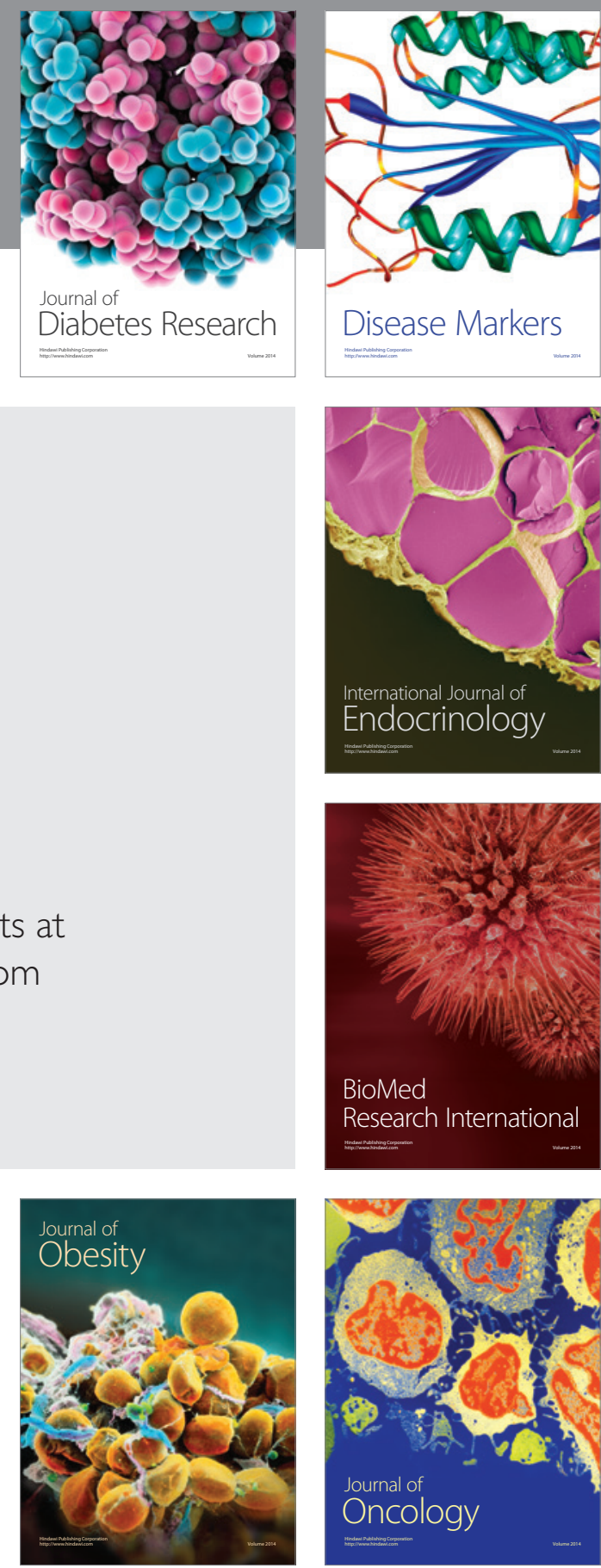

Disease Markers
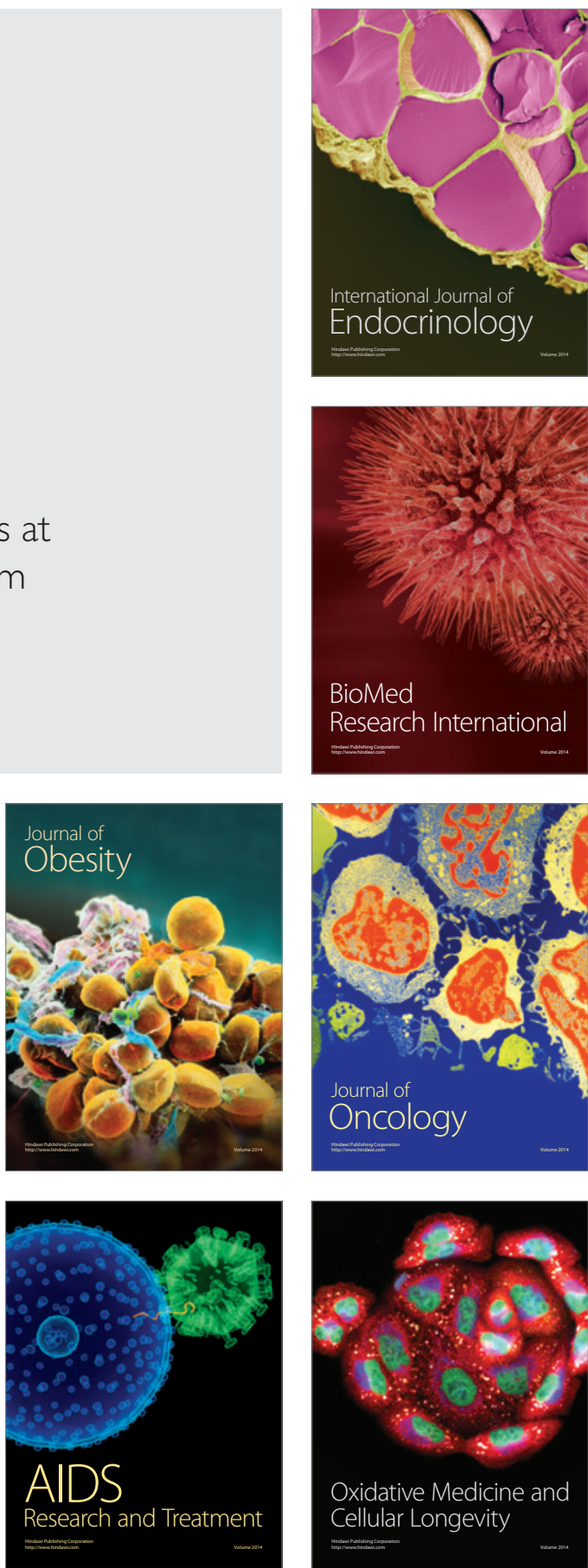